\title{
The Role of Staff in Quality Improvement in Early Childhood
}

\author{
Margaret Sims ${ }^{1}$, Manjula Waniganayake ${ }^{2}$, \\ ${ }^{1}$ University of New England, Armidale, New South Wales, 2351, Australia \\ ${ }^{2}$ Macquarie University, Sydney, New South Wales, 2109, Australia \\ Correspondence: Margaret Sims, School of Education, University of New England, Armidale, NSW, 2351, Australia
}

Received: July 10, 2015 Accepted: July 21, $2015 \quad$ Online Published: July 31, 2015

doi:10.11114/jets.v3i5.942 URL: http://dx.doi.org/10.11114/jets.v3i5.942

\begin{abstract}
There is international recognition of the importance of high quality services for young children with a consensus that three pillars contribute to quality improvement: adult: child ratios, staff qualifications and group size. In Australia over the past 5 years, early childhood policy has attempted to drive improvements in early childhood service quality through national regulations for both adult: child ratios and qualifications. However, a review of early childhood history demonstrates that service quality in the past tended to depend more on the dedication of staff who were expected to be emotionally rewarded through their caring roles rather than from the pay and status associated with their work. The current political direction in Australia is now tending again towards this latter position. We review the literature associated with both positions in relation to quality improvement and flag our concerns for the future.
\end{abstract}

Keywords: early childhood workforce, quality, child care

\section{Introduction}

The commitment to improve quality in early childhood (EC) services arises from recognition of the major contribution experiences in the early years of life make towards life-long outcomes: children in high quality EC services grow up to be healthier, more productive adults and investments in the early years are now recognised internationally as sound economic drivers for the well-being of the nation (Institute for a Competitive Workforce, 2010; Sims, 2013; Walker et al., 2011; Britto, Engle \& Super, 2013). One of the key factors contributing to service quality is the quality of staff. Internationally there has in the recent past been a focus on improving service quality through improving levels of staff qualifications. More recently in Australia, this focus is being questioned and there is a proposal that staff qualifications (specifically for those working with children under 3 years) should be diluted significantly and that quality of service delivery should rely on the dedication and passion of staff because of their innate commitment to children. In this paper we examine the two approaches to quality improvement and raise our concerns about the future directions proposed for Australian EC services.

\section{Quality Comes from Dedicated, Passionate Staff Who Do Not Need High Levels of Qualifications}

In order to examine this position it is necessary to pause and review the history of early childhood services in Australia. Kindergartens were developed in order to educate mothers and their children from disadvantaged economic backgrounds with the aim of counterbalancing the deleterious influences of poverty (Brennan, 1994). In other words, kindergartens were vehicles of social reform through education (Roberts \& Kingston, 2001a). It was anticipated that by spending time at the kindergarten to learn appropriate mothering skills, mothers would be reformed. Children themselves would be reformed through the shaping explicit in the kindergarten curriculum which aimed to create good citizens for the nation. In effect, these mothers and children were explicitly taught middle class norms by middle class kindergarten teachers (Sims \& Hutchins, 2011). For example, in 1907, Maybanke Anderson wrote:

Every kindergarten is managed by a director, who, with many assistants, tries to lay a foundation for character in the children by training them in habits of truthfulness and courtesy. They help them to love cleanliness and order. They teach them to observe accurately, to express themselves with precision, and by manual training of many kinds they develop deft fingers and a desire for useful work (Roberts \& Kingston, 2001b, p.212).

This focus of education as a tool for social reform has continued: for example, it is evident in the introduction of Head Start in America, coupled with several key experimental early intervention programmes such as Perry High Scope (Sims, 
1994). In contrast, child care services (day nurseries) arose from a welfare context: to provide child care for working mothers (Sims \& Hutchins, 2011). In 1907 Maybanke Anderson wrote:

The children of the drunken and the dissolute, of the deserted wife, who earns a bare living while they play in the street; the children of the incapable, and of those who by birth or training are useless and utterly irresponsible, the coming citizens - they gather in the gutters of the narrow byways, and even in their chatter and their play, one who knows how to listen may hear a menace for the future (Roberts \& Kingston, 2001b, p. 212).

Given that mothers only worked if they were living in poverty or were sole parents, this need for child care was perceived as a problem and appropriate care for their children (to prevent them living on the streets and becoming a threat) was focused on physical wellbeing (having appropriate food, clothing and learning appropriate hygiene habits). Learning academics, including maths and reading, was not part of the mandate of these early day nurseries and staff working in them were trained in nursery nursing, not kindergarten teaching.

The ideal situation was constructed as mother-care supported by the part-time education offered by kindergartens. Mothers needing additional support were positioned as lacking and in need of instruction in order to be able to properly care for their children (Davis, 1988). This focus on good mothering was later supported by the work of Bowlby (1969, 1988) who introduced the concept of maternal deprivation. He argued, based on his work in orphanages, that the attachment relationship between mother and child was essential for children's development. This work was then taken to mean that placing children in child care was not desirable: they should be in the care of their mothers. Although Bowlby's work never examined the impact of child care settings, it was used in the 1950s and 1960s to argue against working mothers and their need for expanded child care services (Brennan, 1994) and many saw it as scientific evidence justifying mothers' role in the home.

In this context, quality of child care (as distinct from kindergarten) was not considered important. Child care services, were, after all, for those women who were NOT good mothers, or who were forced through economic circumstances to find paid employment. Thus quality improvement in these services was not taken seriously for decades. In contrast, quality of the educational offerings in kindergartens was taken for granted as a given. In order to fulfill this objective, early childhood pioneers such as Maybanke Anderson argued there needed to be appropriate training courses for young middle class women wanting to teach in kindergartens:

The young women who do all this need special preparation. It is not light work, and few indeed, if any, are born kindergarteners. Two years of training are necessary, and the K.U. maintains a college where young women over eighteen are received and prepared to take charge of children, either in a home or in a kindergarten (Roberts \& Kingston, 2001b, p. 212).

Training for kindergarten teaching was established in Australia in 1885 beginning with private colleges and the Kindergarten Union of NSW. Examination and certification of kindergarten teachers was taken over by the Teachers' Association in 1903 (Roberts \& Kingston, 2001a) and kindergarten teachers spread across Australia. The two year training set up by the Kindergarten Union of NSW, in operation by 1907, is reflected today in the vocational Diploma level qualification (a nominally 2 year course). However, in the past, whilst Diploma level qualifications were recognised for kindergarten teaching, today, this level is recognised for child care but no longer for early childhood teaching. This division between child care and education, arising from the association of motherhood with child care and education with kindergartens, has resulted in today's lack of appreciation of child care work and the subsequent de-valuing of this work as a profession (Nuttall, 1992).

This history leads us to the alternative approach taken in the most recent Productivity Commission (2014) review on early childhood service quality improvement. The very title of the report "Child care and early childhood learning" clearly positions the care and education elements as mutually exclusive: a position evolving from the history of early childhood services briefly discussed above. This separation implies that children do not learn in child care, and that education services are not responsible for care. Indeed, this position is clearly articulated by the Productivity Commission (2014): "ECEC for children aged birth to three should focus on quality care and not be required to include a significant educational component" (p227).

This separation of care and education is a movement that appears to be taking hold internationally (Ang, 2014). There are international concerns about the consequent emphasis on preparation for school (Kaga, Bennett, \& Moss, 2010) to the exclusion of children learning for functionality and success in their own unique ecological niche. This positions children as future citizens who are to attend early childhood services in order to be prepared for a school experience that will shape them to become productive, contributing members of society. In order to achieve these outcomes, governments around the world are focusing increasingly on (Ang, 2014): 
... educational attainments, assessment and learning goals, thereby devaluing the early years experience for young children ... (p. 191) ... the pedagogy of supporting children's learning during the early years is becoming increasingly formalised and academic ... holistic educational experience is somewhat lost in the drive towards targets and attainment, especially when assessment is used as a policy tool in education (p. 192).

This then leads to a different perspective on quality improvement. Quality improvement in the care sector is not seen as an issue and it can appropriately be driven by poorly qualified staff who perform their work out of a sense of dedication and passion, rather than from the sound combination of theoretical and practical experience expected of teachers. The Productivity Commission (2014, p. 277) report argues:

LDC services should be able to provide care for children under 36 months without the oversight of a teacher and these children should not be included in the count towards the requirement to hire an early childhood teacher (ECT). This would allow ECTs to focus on children aged 36 months and over. The Commission also considers that all LDC workers caring for children aged under 36 months should be required to hold or be actively working towards a certificate III or equivalent (the same qualification expected of family day care educators), rather than half of these educators being required to hold or be working towards a diploma level qualification.

Note that a Certificate III level qualification is defined by the Australian Government as suitable for those who need to complete routine activities and provide solutions to mainly predictable problems. A Certificate III qualification is often completed in 6 months post completion of secondary school and is part of the vocational education sector (http://www.aqf.edu.au/aqf/in-detail/aqf-levels/).

The idea that people work in early childhood, not because of pay or status, but because they are committed to young children is an idea that also has its origins in the past; and within the ideology of traditional motherhood which positions women as natural carers (Johnston \& Swanson, 2003; Sims, 1994). It is no coincidence that there are very few men working in early childhood services and there are many who believe that men should not be working with young children (Yarrow, 2010). Men are expected to work for pay; women on the other hand, should work for emotional rewards. Women are expected to be dedicated and passionate about work that supports their innate caring role (Pocock, 2005). This idea continues to receive community support. The Productivity Commission argues (2014, p. 482):

ECEC staff are attracted to the industry based on their passion for children and while they would prefer higher wages, generally they demonstrate a willingness to work in the sector at current wages and conditions.

Quality improvement in child care services then is positioned as something that is not particularly important. What improvements there are can be driven by staff with a low level of qualifications (note that the 2 year kindergarten diploma in place by 1906 offered a higher level of training than the currently proposed Certificate III), who are poorly paid but in the job because of their commitment to children. This is a very different stance to that which positions the early years as crucial and thus needing highly trained staff who are capable of driving quality improvement through their pedagogical leadership.

\section{Quality Comes from the Leadership of Highly Qualified Staff}

Research from around the world demonstrates that better qualified staff with access to appropriate resources and support can significantly improve the quality of service delivery (Ebbeck \& Waniganayake, 2004; Hadley, 2013; Organisation for Economic Co-operation and Development, 2012; Rentzou \& Sakellariou, 2011; Siraj-Blatchford \& Manni, 2007). Well-qualified EC graduates can support, role model and mentor by using pedagogical knowledge to act with courage and purpose in driving social change and quality improvement (Hard, Press, \& Gibson, 2013). Of course qualifications have to be relevant to the required roles: that is, higher levels of general education do not in themselves drive quality improvement in a specific profession.

Relevant staff qualifications are an important driver of quality improvement. In the UK, for instance, efforts to improve quality in EC services in the last decade were based on the development of a national advanced professional qualification - the Early Years Professional Status (EYPS). Highly skilled graduate teachers with several years experience in EC were able to take this additional training. Research has clearly demonstrated that the impact of this policy directive has been significant (Clark, 2012; Mathers et al., 2011; Siraj-Blatchford, Sylva, Muttock, Gilden, \& Bell, 2002). Graduates of the course were more confident in mentoring and supporting colleagues to improve quality and more confident in leading improvements in their service (Hadfield et al., 2012). The EYPS graduates were responsible for an overall increase in the quality of a service, and were much more effective when they themselves were 
working hands-on with children. The more time an EYPS graduate spent in the classroom with children, the more the overall quality of the service improved (Sylva, Melhuish, Sammons, Siraj-Blatchford, \& Taggart, 2010).

Driving quality improvement in service delivery through improved qualifications depends not only on the relevance of the EC qualifications but on the ability of graduates to take on a pedagogical/educational leadership role. Those who are the most effective leaders are those who self-identify as leaders. This is supported by research that demonstrates a strong link between internalised identity and situated action (Owens, Robinson, \& Smith-Lovin, 2010), between self identity and behavioural intentions and a further very strong link between behavioural intentions and actual behaviour at the coalface of service delivery (Rise, Sheeran, \& Hukkelberg, 2010). Thus developing an identity of self-as-a-leader is important in facilitating appropriate leadership behaviour. Early childhood educators who BELIEVE in themselves as educational leaders are more likely to have a positive impact on quality compared to those whose professional identity positions them as EC educators without an educational leadership role. A secure professional identity, where educators feel clear about their role and confident in their capability to teach, has been shown to contribute to improvements in work performance (quality), workforce retention and commitment to the profession through their enacted leadership (Watt \& Richardson, 2008).

This approach of employing well qualified EC leaders to drive quality improvement used in the EYPS and the current Australian National Quality Framework (NQF), are modeled on the concept of distributed leadership: the idea that leadership operates in a social context and people take on various components of the role through mutual negotiation in each context (DeRue \& Ashford, 2010). This policy direction reflects international research findings (Murray \& McDowall Clark, 2013). As can be seen in EC centres in Finland, this positions educational leadership as the core business of EC educators/leaders (Heikka, Waniganayake, \& Hujala, 2013): the assumption in Finland is that ALL educators with university degrees in EC are expected to be educational leaders. The UK research cited earlier also suggests that removing EYPS graduates from their hands-on work with children and placing them in administrative leadership positions where they spent more time in an office (as line managers rather than educational leaders) was counter-productive. In reviewing the impact of the EYPS graduates in the UK, Clark (2012) argued educational leadership is a new form of leadership described as 'catalytic leadership'. This type of leadership, where the leader inspires changes in the quality of service delivery, emerges from a position independent of power. Instead, leadership is effective through the relationships built with other staff members.

In Australian research Hadley (2012) found that involvement of an external consultant as a critical friend can be effective in stimulating and sustaining real change in pedagogical practice within EC centres. Likewise, in their national study involving over 530 childcare centre directors around Australia, Waniganayake et al. (2008) found “... the perceived value of professional development and support is dependent upon the leadership demonstrated by the centre director/manager/owner operator" (p.70). Although this research was done prior to the introduction of the National Quality Framework (NQF), mentoring and role modeling by centre directors were found to be important elements of creating a culture of learning within EC centres.

There is a growing demand for EC teachers due to both the expansion of services and the regulatory requirements introduced at the same time as the NQF (eg both preschools and childcare centres with 25 children or more were expected to employ at least one university qualified teacher by 1 January 2014 - Australian Children's Education and Care Quality Authority, 2013). However, this policy is now under review. The number of places in EC teacher education degrees also requires monitoring due to potential government restrictions on funding tertiary education (Fenech, Waniganayake, \& Fleet, 2009; Productivity Commission, 2011). Poor pay and conditions combined with poor parity with school teacher salary and conditions, impact heavily on the ability to attract able students and retain well qualified EC teachers (Ailwood \& Boyd, 2006; Bretherton, 2010; Early Childhood Australia, 2011; Productivity Commission, 2011, 2014; Sumsion, 2007; Thorpe, Boyd, \& Brownlee, 2011), making it difficult for many EC services to meet their regulatory requirements (Australian Children's Education and Care Quality Authority, 2013). In a context of an increasing trend for universities to offer Birth -12 years teacher qualifications, many jointly trained Early Childhood/Primary teachers seek employment in the superior workforce conditions offered in schools (Early Childhood Australia, 2011; Productivity Commission, 2011). Less favourable conditions in the EC sector include longer hours of work, limited resources, poor pay and lower job status (Bretherton, 2010; Productivity Commission, 2011, 2014; Sims, 2007), resulting in the marginalisation of early childhood as a profession (Fenech et al., 2009). Strong anecdotal evidence suggests that many EC teachers leave the profession within 5 years post-graduation, meaning that educational leadership for quality improvement is left to their less experienced/less qualified colleagues with consequent implications for program quality and children's learning.

Thus the current context in Australia is one where there is an intention to drive quality improvement in EC services through legislative requirements for 4 year, university trained EC teachers (numbers of which are mandated based on the number of children in a service). However, the implementation of this vision to drive quality improvement is 
somewhat hampered by logistical considerations. According to the Childcare Workforce Census for 2013, only $11.4 \%$ of the EC workforce had achieved a four year Bachelor degree. This lack of well qualified EC teachers, when combined with the cost of employing such teachers and the poor retention of graduates in the profession, all impact on the financial viability of services. It is in this climate that the recent review undertaken by the Productivity Commission (2014) was released. This review not only positions EC services very differently, but holds a very different perspective on the drivers of quality improvement as discussed above.

\section{Conclusion}

It is of concern that in their sweep of the international landscape on ECEC, the Productivity Commission draws attention to the fact that some OECD countries such as Sweden, which achieve high ratings in international benchmarking exercises (see Adamson, 2008; Economist Intelligence Unit, 2012) do not have mandated child to staff ratios but rather ensure quality through qualifications (Productivity Commission, 2014). Likewise, the report also notes the use of social pedagogues rather than traditional teachers in many EU countries, and the absence of mandatory qualifications for EC staff in the USA. These comments by the Productivity Commission, muddies long standing research evidence which attributes staff qualifications, staff to child ratios and group size as being the three structures that dictate quality service provision in the early childhood sector. Yet, the Productivity Commission (2014) declares:

Having nurturing, warm and attentive carers is arguably the most critical attribute of quality in any ECEC setting, especially for younger children. Other factors affecting quality include: staff-to-child ratios; qualifications, skills and training of staff; program planning and leadership; and the physical environment/facilities. There is, however, little reliable evidence on the relative contribution that each of these makes to child development outcomes.

Given the challenges of running randomised controlled trials to assess the veracity of relationships between staff input and child outcomes from a long-term perspective, what should policy makers do? When asked about his policy recommendations for bachelor level qualifications for teachers, Steve Barnett, co-director of the National Institute for Early Education Research replied:

To me when we're dealing with policy, when we're unsure, I think we have to ask 'what is the cautious thing to do?' I think moving away from programs with highly educated, well-paid teachers is an incautious thing to do given the evidence (Institute of Medicine (IOM) and National Research Council (NRC), 2012, p. 48)

Having well qualified teachers obviously can do no harm! How can we maximise the potential growth value of early childhood prior to starting school, in particular, during the first three years of life? So far, the Productivity Commission (2014) has failed to justify the case for not mandating the employment of university qualified early childhood teachers. With the consolidation of the educational leader's role in leading pedagogy, and the recognition of master teachers with sound qualifications and experience to lead this work, the evidence base will continue to grow.

Where does this leave quality of early childhood services in Australia? Certainly should these changes actually be imposed service quality must decline: services struggling to meet minimum accreditation standards now will be less able to achieve these targets with greater numbers of staff holding low level qualifications. Given that experiences in the very early years are crucial in shaping the future adult, and the government's proposed positioning of education as starting at 3 years of age and not before, there is a significant risk that Australia's competitiveness in the international market will decline. We owe our youngest children the best possible quality early childhood experiences. If the state is not willing to invest to ensure better outcomes for our children, who will?

\section{References}

Adamson, P. (2008). The child care transition. A league talbleof early childhood education and care in economically advanced countries (pp. 40). Florence: UNICEF Innocenti Research Centre. Available at www.unicef-irc.org

Ailwood, J., \& Boyd, W. (2006). First year early childhood education students' beliefs about children in long day child care. Paper presented at the Paper presented at the Australian Teacher Education Association conference, Fremantle, WA.

Ang, L. (2014). Preschool or Prep School? Rethinking the role of early years education. Contemporary Issues in Early Childhood, 15(2), 185-199. http://dx.doi.org/10.2304/ciec.2014.15.2.185

Australian Children's Education and Care Quality Authority. (2013). Annual Report (pp. 136): Australian Children's Education and Care Quality Authority. http://files.acecqa.gov.au/files/Annual\%20Report/ACECQA-AnnualReport2013.pdf

Bowlby, J. (1969). Attachment and loss. (Vol. 1). New York: Basic Books. 
Bowlby, J. (1988). A secure base: parent-child attachment and healthy human development. London: Routledge.

Brennan, D. (1994). The politics of Australian child care: from philanthropy to feminism. Melbourne: Cambridge University Press.

Bretherton, T. (2010). Developing the childcare workforce: Understanding 'fight' or 'flight' amongst workers. Adelaide: National Centre for Vocational Education Research (NCVER). http://files.eric.ed.gov/fulltext/ED510849.pdf

Britto, P. R., Engle, P. L., \& Cuper, C. M. (2013). Handbook of early childhood development research and its impact on global policy. London: Oxford University Press. http://dx.doi.org/10.1093/acprof:oso/9780199922994.001.0001

Clark, R. (2012). 'I've never thought of myself as a leader but...': the Early Years Professional and catalytic leadership. European Early Childhood Education Research Journal, 20(3), 391-401. http://dx.doi.org/10.1080/1350293X.2012.704762

Davis, A. (1988). Infant mortality and child saving. In P. Hetherington (Ed.), Childhood and society in Western Australia (pp. 161 - 173). Pdererth: University of Western Australia Press.

DeRue, S., \& Ashford, S. (2010). Who will lead and who will follow? A social process of leadership identity construction in organisations. Academy of Management Review, 35, 627-647. http://dx.doi.org/10.5465/AMR.2010.53503267

Early Childhood Australia. (2011). Early childhood education and care in Australia. A discussion paper prepared for the European Union-Australia Policy Dialogue, 11 - 15 April. Canberra, ACT: Early Childhood Australia.

Ebbeck, M., \& Waniganayake, M. (2004). Early Childhood Professionals: Leading today and tomorrow. Sydney: Elsevier Australia.

Economist Intelligence Unit. (2012). Starting Well: Benchmarking early education across the world London: EIU. http://www.economistinsights.com/sites/default/files/legacy/mgthink/downloads/Starting\%20Well.pdf

Fenech, M., Waniganayake, M., \& Fleet, A. (2009). More than a shortage of early childhood teachers: Looking beyond the recruitment of university qualified teachers to promote quality early childhood education and care. Asia-Pacific Journal of Teacher Education, 37(2), 199-213.

Hadfield, M., Jopling, M., Needham, M., Waller, T., Coleyshaw, L., Emira, M., \& Royle, K. (2012). Longitudinal Study of Early Years Professional Status: an exploration of progress, leadership and impact. Final report (Vol. DFE-RR239c). Wolverhampton: CeDare, University of Wolverhampton. https://www.gov.uk/government/uploads/system/uploads/attachment_data/file/183418/DfE-RR239c_report.pdf

Hadley, F. (2012). Rethinking pedagogical practices. How can teachers in early childhood settings be supported professionally to examine their practices? . In P. Whiteman \& K. De Gioia (Eds.), Children and Childhoods 1: Perspectives, places and practices (pp. 16 - 35). Newcastle upon Tyne, UK: Cambridge Scholars Publishing.

Hadley, F. (2013). Lessons learnt-the Early Years Learning Framework, early childhood teachers' professional learning and the leader's role. Every Child, 19(2), 20-21.

Hard, L., Press, F., \& Gibson, M. (2013). 'Doing' Social Justice in Early Childhood: the potential of leadership. Contemporary Issues in Early Childhood, 14(4). http://dx.doi.org/10.2304/ciec.2013.14.4.324

Heikka, J., Waniganayake, M., \& Hujala, E. (2013). Contextualising distributed leadership within early childhood education: Current understandings, research evidence and future challenges. Educational Management Administration \& Leadership, 4l(1), 30 - 44. http://dx.doi.org/10.1177/1741143212462700

Institute for a Competitive Workforce. (2010). Why Business Should Support Early Childhood Education. (pp. 43). Washington DC: Institute for a Competitive Workforce, US Chamber of Commerce. http://www.uschamberfoundation.org/publication/ready-set-go-why-business-should-support-early-childhood-educ ation

Institute of Medicine (IOM) and National Research Council (NRC). (2012). The early childhood care and education workforce: Challenges and opportunities. A workshop report. Washington DC: The National Academies Press. http://www.nap.edu/catalog/13238/the-early-childhood-care-and-education-workforce-challenges-and-opportunities

Johnston, D., \& Swanson, D. (2003). Invisible mothers: A content analysis of motherhood ideologies and myths in magazines. Sex Roles, 49, 21-33. http://dx.doi.org/10.1023/A:1023905518500

Kaga, Y., Bennett, J., \& Moss, P. (2010). Caring and learning together. A cross-national study on the integration of early childhood care and education within education (pp. 141). Paris: UNESCO. http://unesdoc.unesco.org/images/0018/001878/187818e.pdf 
Mathers, S., Ranns, H., Karemaker, A., Moody, A., Sylva, K., Graham, J., \& Siraj-Blatchford, I. (2011). Evaluation of the Graduate Leader Fund Final report. London: Department for Education. https://www.gov.uk/government/publications/evaluation-of-the-graduate-leader-fund-final-report

Murray, J., \& McDowall Clark, R. (2013). Reframing leadership as a participative pedagogy: the working theories of early years professionals. Early Years: An International Research Journal, 33(3), 289-301. http://dx.doi.org/10.1080/09575146.2013.781135

Nuttall, J. (1992). Women, capitalism and feminism: workers' experiences in private and non-profit child care centres. (Master of Education), University of Cantebury, Christchurch. http://ir.canterbury.ac.nz/handle/10092/2355

Organisation for Economic Co-operation and Development. (2012). Starting Strong III - A quality toolbox for early childhood education and care: OECD Publishing. http://dx.doi.org/10.1787/9789264123564-en

Owens, T., Robinson, D., \& Smith-Lovin, L. (2010). Three Faces of Identity. 36, 477-499. http://dx.doi.org/10.1146/annurev.soc.34.040507.134725

Pocock, B. (2005). Mothers; the more things change the more they stay the same. In M. Poole (Ed.), Families: changing families, changing times (pp. 113 - 134). Crows Nest, NSW: Allen \& Unwin.

Productivity Commission. (2011). Early Childhood Development Workforce. Melbourne, Vic: Productivity Commission. http://dx.doi.org/10.2139/ssrn.2006081

Productivity Commission. (2014). Child care and early childhood learning. Productivity Commission Draft Report (pp. 918). Canberra, ACT: Commonwealth of Australia.

Rentzou, K., \& Sakellariou, M. (2011). The Quality of Early Childhood Educators: Children's Interaction in Greek Child Care Centers. Early Childhood Education Journal, 38, 367-376. http://dx.doi.org/10.1007/s10643-010-0403-3

Rise, J., Sheeran, P., \& Hukkelberg, S. (2010). The role of self-identity in the theory of planned behaviour: a metaanalysis,. Journal of Applied Social Psychology, 40(5), 1085-1105. http://dx.doi.org/10.1111/j.1559-1816.2010.00611.x

Roberts, J., \& Kingston, B. (Eds.). (2001a). Maybanke. A woman's voice. The collected works of Maybanke Selfe Wolstenholme Anderson 1845 - 1927. Avalon Beach, NSW: Ruskin Rowe Press.

Roberts, J., \& Kingston, B. (Eds.). (2001b). Maybanke. A woman's voice. The collected works of Maybanke Selfe Wolstenholme $\sim$ Anderson 1845-1927. Avalon Beach, NSW: Ruskin Rowe Press.

Sims, M. (1994). Care and Education: Revisiting the dichotomy. Early Child Development and Care, 103, 15-26. http://dx.doi.org/10.1080/0300443941030102

Sims, M. (2007). The determinants of quality care: Review and research report. . In E. Hill, B. Pocock \& A. Elliot (Eds.), Kids Count: Better early education and care in Australia. (pp. 220 - 241). Sydney: University of Sydney Press.

Sims, M. (2013). The importance of early years education. In D. Pendergast \& S. Garvis (Eds.), Teaching early years: Curriculum, Pedagogy and Assessment. (pp. 20 - 32). Crows Nest, NSW: Allen and Unwin.

Sims, M., \& Hutchins, T. (2011). Program planning for infants and toddlers. In search of relationships. Castle Hill, NSW: Pademelon Press.

Siraj-Blatchford, I., \& Manni, L. (2007). Effective leadership in the early years sector: the ELEYS study By London, UK: Institute of Education, University of London.

Siraj-Blatchford, I., Sylva, K., Muttock, S., Gilden, R., \& Bell, D. (2002). Researching effective pedagogy in the early years. DfES Research Report 356. London: Department for Education and Skills, HMSO.

Sumsion, J. (2007). Sustaining the employment of early childhood teachers in long day care: A case for robust hope, critical imagination and critical action. Asia Pacific Journal of Teacher Education, 35(3), 311-327. http://dx.doi.org/10.1080/13598660701447247

Sylva, K., Melhuish, E., Sammons, P., Siraj-Blatchford, I., \& Taggart, B. (Eds.). (2010). Early childhood matters. Evidence from the Effective Pre-school and Primary Education Project. Oxon: Routledge.

Thorpe, K., Boyd, W., \& Brownlee, J. (2011). Who wants to work in child care? Pre-service early childhood teachers' consideration of work in the childcare sector. Australasian Journal of Early Childhood, 36(1), 85-94.

Walker, S., Wachs, T., Grantham-McGregor, S., Black, M., Nelson, C., Huffman, S., . . Richter, L. (2011). Inequality in 
early childhood: risk and protective factors for early child development. The Lancet, 378, 1325-1338. http://dx.doi.org/10.1016/S0140-6736(11)60555-2

Waniganayake, M., Harrison, L., Cheeseman, S., Burgess, C., De Gioia, K., \& Press, F. (2008). Practice potentials. Impact of participation in professional development and support on quality outcomes for children in childcare centres. Research report commissioned by the Professional Support Coordination Alliance (PSCA). Canberra: Professional Support Coordinators Alliance, Access Macquarie Limited, Department of Education, Employment and Workplace Relations.

Watt, H., \& Richardson, P. (2008). Motivations, perceptions and aspirations concerning teaching as a career for different types of beginning teachers. Leading and Instruction, 18, 408-428. http://dx.doi.org/10.1016/j.learninstruc.2008.06.002

Yarrow, A. (2010). I'm not a man I'm a teacher. Every Child, 16(1), 3.

This work is licensed under a Creative Commons Attribution 3.0 License. 